\title{
ANALISIS KONTRASTIS BAHASA JAWA DENGAN BAHASA INDONESIA
}

Oleh :

Riris Tiani

Fakultas Ilmu Budaya Undip

\begin{abstract}
Dari pemaparan dalam bagian pembahasan di atas, dapat disimpulkan bahwa bahasa Jawa dan bahasa Indonesia dapat diketahui struktur fonologi, morfologi, dan sintaksis. Dari pemaparan itu pula, dapat diketahuai adanya perbedaan yang mencolok dalam struktur fonologi, morfologi, dan sintaksis.

Dalam ranah fonologi terdapat perbedaan tentang keberadaan fonem segmental dan fonem suprasegmental dalam bahasa Jawa, jumlah bunyi vokal bahasa Jawa lebih banyak.
\end{abstract}

Kata Kunci: Kontrastif, fonologi, morfologi, preposisi.

\section{PENDAHULUAN}

\subsection{Latar Belakang}

Bahasa merupakan alat komunikasi yang paling efektif untuk menyampaikan gagasan, pikiran. Maksud dan tujuan kepada orang lain dan selain itu bahasa merupakan salah satu unsur kebudayaan. Dengan demikian seseorang perlukan mempelajari secara mendalam atau mengadakan penelitian terhadap suatu bahasa baik bahasa Indonsia maupun bahasa daerah yang dimiliki Nusantara.

Bahasa yang ada di Nusantara sangat beragam. Tak kurang dari seratus lima puluh bahasa hidup dan berkembang dengan baik. Beragamnya bahasa tersebut memungkinkan adanya studi tentang kebahasaan baik dari aspek fonologi, morfologi, sintaksis, serta semantik.

Begitu juga dengan bahasa Jawa merupakan bahasa daerah yang paling banyak penuturnya di Indonesia. Selain karena memang penghuni pulau jawa terpadat dan terbanyak, ternyata suku Jawa memang sudah tersebar ke segala penjuru nusantara. Bahasa Jawa dapat berkembang dengan baik secara beriringan dengan perkembangan bahasa Indonesia sebagai lingua franca.
Oleh karena itu bahasa Jawa dan bahasa Indonesia memiliki kaunikan yang layak untuk diteliti lebih lanjut.Penelitian dengan cara analisis kontrastif antara bahasa Jawa dengan bahasa Indonesia ditinjau dari segi linguistiknyaterutama pada aspek fonologi, morfologi.

\subsection{Rumusan Masalah}

1. Bagaimana struktur fonologi, morfologi bahasa Jawa dan bahasa Indonesia?

2. Bagaimana bentuk kontrastif fonologi, morfologi bahasa Jawa dan bahasa Indonesia?

\subsection{Landasan Teori}

Kata Kontrastif berasal dari perkataan Contrastive yaitu kata keadaan yang diturunkan dan kata kerja to contras artinya berbeda atau bertentangan. Dalam The american College Dictionary terdapat penjelasan sebagai berikut Contras : to set in opposition in order to show unli keneses, compare by observing differences. Artinya : menempatkan dalam oposisi atau pertentangan dengan tujuan memperlihatkan ketidaksamaan, memperbandingkan dengan jalan memperhatikan pebedaan-perbedaan. 
Penjelasan tersebut penelitik dapat menarik kesimpulan, bahwa yang dimaksud dengan istilah linguistik kontrastif adalah ilmu bahasa yang meneliti perbedaan-perbedaan,

ketidaksamaanketidaksamaan

yang terdapat pada pula dua bahasa atau lebih yang tidak serumpun.

Linguistik kontrastif komparatif adalah ilmu bahasa yang meneliti persamaan dan perbedaan dengan cara membandingkan dua bahasa atau lebih yang serumpun. Misalnya komparatif bahasa daerah dengan bahasa Indonesia.

Linguistik kontrastif pada dasarnya hanya meneliti perbedaan-perbedaan atau ketidaksamaan-ketidaksamaan yang nyolok yang terdapat pada dua bahasa atau lebih yang tidak serumpun, sedangkan persamaan-persamaannya tidak begitu dipentingkan atau diperhatikan. Kesamaankesamaan yang ada di anggap sebagai hal yang biasa atau hal umum saja.

Studi kontrastif adalah suatu studi yang mempunyai peranan penting dalam proses mengajar bahasa asing. Dalam proses mengajara bahasa, yang paling penting adalah menentukan aspek-aspek kesamaan serta perbedaan dua bahasa yang diperbandingkan.

Analisis kontrastif adalah suatu metode analisis pengkajian kontrastif, ini menunjukan kesamaan dan perbedaan antara dua bahasa dengan tujuan untuk menemukan prinsip yang dapat diterapkan pada masalah praktis dalam pengajaran bahasa atau terjemaannya.

Kesimpulannnya linguistik kontrastif merupakan salah satu cabang linguistik yang fungsinya mengontraskan dua bahasa atau lebih tidak serumpun dan linguistik kontrastif dapat membantu kesulitan yang mungkin dialami seseorang dalam mengajarkan bahasa yang berbeda rumpun bahasanya, ataupun bagi seseorang yang bela jar bahasa asing yang rumpun bahasanya berbeda.

\section{PEMBAHASAN 2.1 FONOLOGI \\ 2.1.1 Bahasa Jawa}

Fonologi dalam bahasa Jawa widyaswara merupakan cabang linguistic yang mempelajari sistem bunyi bahasabahasa. Fonogi telah didefenisikan sebagai kajian system bunyi, adalah suatu kajian bagaimana struktur dan fungsi bunyi ujaran dalam bahasa-bahasa. Klasifikasi bunyi bahasa:

1. Klasifikasi bunyi bahasa berdasarkan rongga yang dilewati udara:

a. Bunyi oral

Adalah bunyi bahasa yang proses pembentukannya udara mengalir melalui rongga mulut. Yaitu sebagai berikut: $[\mathrm{p}],[\mathrm{t}],[\mathrm{c}],[\mathrm{k}],[\mathrm{b}]$, [d], [j], [g], [s], [h], [l], [r], [w], [y], dan [?].

b. Bunyi nasal

Adalah bunyi bahasa yang dalam proses pembentukannya udara yang keluar dari paru-paru mengalir melalui rongga hidung. Yaitu sebagai berikut: $[\mathrm{m}],[\mathrm{n}],[\mathrm{k}]$, dan [n].

2. Klasifikasi bunyi bahasa berdasarkan ada tidaknya proses artikulasi:

a. Bunyi vokal

Adalah bunyi bahasa yang dalam proses pembentukannya udara yang keluar dari paru-paru tidak mengalami proses artikulasi. Vokal bulat bahasa Jawa adalah: [u], [U], [o], dan [e] sedangkan Vokal tak bulatnya [i], [I], [e], [U], [a], dan [Q].

b. Bunyi konsonan

Adalah bunyi bahasa yang dihasilkan dengan adanya proses artikulasi, yakni dengan dihambatnya aliran udara yang keluar masuknya paru-paru pada salah satu tempat di saluran udara di atas glotis atau di salah satu alat ucap manusia. 
3. Klasifikasi konsonan berdasarkan alat ucap:
a. Artikulasi bunyi bilabial: [p], [b], dan $[\mathrm{m}]$
b. Artikulasi bunyi labio-dental: [f], $[\mathrm{w}]$ dan $[\mathrm{v}]$
c. Artikulasi bunyi apiko-dental: [t], [d]
d. Artikulasi bunyi apiko-alveolar: [n], [1], dan [r]
e. Artikulasi bunyi apiko-palatal: [p], [d]
f. Artikulasi bunyi lamino alveolar: [s] dan [z]
g. Artikulasi bunyi medio-palatal: [c], [j], [y]
h. Artikulasi bunyi dorso-velar: [k], $[\mathrm{g}],[\mathrm{K}]$, dan $[\mathrm{x}]$
i. Artikulasi bunyi uvular: [R]

4. Klasifikasi konsonan berdasarkan jenis hambatan
a. Konsonan letup: [p], [b], [d], [t], $[\mathrm{d}],[\mathrm{c}],[\mathrm{j}],[\mathrm{k}],[\mathrm{g}]$, dan [?]
b. Konsonan geser: [f], [v], [s], [z], $[\mathrm{x}]$, dan [h]
c. Konsonan lateral: [1]
d. Konsonan getar: [r]
e. Konsonan afrikat: $[\mathrm{t}]$ dan $[\mathrm{d}]$
f. Bunyi semi Vokal: [w] dan [y]

\subsection{MORFOLOGI}

Morfologi didefenisikan olah banyak ahli antara lain, Ramlan (1985:18) menguraikan morfologi sebagian bagian dari ilmu bahasa yang bidangnya menyelidiki seluk beluk bentuk kata, dan kemungkinan adanya perubahan golongan dan arti kata yang timbul sebagai akibat perubahan bentuk kata.

\subsubsection{Proses morfologi bahasa Jawa}

a. Proses pengimbuhan atau Wuwuhan

Wuwuhan adalah proses pengimbuhan pada satuan bentuk tunggal atau bentuk kompleks untuk membentuk morfem baru atau satuan yang lebih luas.

b. Pengimbuhan di depan atau Ater-ater Pengimbuhan ater-ater adalh proses pengimbuhan morfem tunggal atau kompleks dengan morfem ikat yang disebut atre-ater yang di letakkan di depan morfem tersebut.

Dalam bahasa Jawa imbuhan di depan memiliki jumlah yang relative cukup banyak. Imbuhan tersebut antara lain: N- (n-, ny-, m-. ng-), dak-/ tak-, kok-/ tok-, di-, ka-, ke-, a-, aN-, paN-, ma-, me-, sa-, pa-, pi-, pra-, tar-, kuma-, kami-, kapi-.

c. Pengimbuhan di tengah atau seselan

Dalam bahasa Jawa pengimbuhan tersebut adalah seselan, atau sisipan dalam bahasa Indonesia. Sisipan dalam bahasa Jawa ada 4 morfem yaitu: -in-, um-, -er-, dan -el-.

d. Pengimbuhan di belakang atau penambang

Imbuhan di belakang atau akhiran dalam bahasa Jawa di sebut panambang. Akhiran dalam bahasa Jawa antara lain: -i, -ake, -a, -en, -na, ana, -an, dan -e

e. Pengimbuhan bersama/ bergantian atau konfliks/ simulfiks

Imbuhan yang melekatnya dengan morfem lain bersamaan atau bergantian dengan imbuhan lain biasa di sebut sebagai morfem konflik atau simulfiks. Imbuhan-imbuhan tersebut adalah: ka/ -an, ke-/ -an, ke-/ -en, N-/ -I, N-/ -ake, $\mathrm{N}-/$-na, paN-/ -an,paN-/ -e, pa-/ -an, pi-/ -an, pra-/ -an, tak-/ -ane, tak-/ -e, tak-/ -I, tak-/ -na, tak-/ -ana, tak-/ -a, kok-/ -I, kok-/ -ake/ -ke, kok-/ -a, kok-/ -na, kok-/ -ana, di-/ -I, di-/ -ake, kami-/ -en, kami-/ -an, sa-/ -e, -in-/ -an.

\subsubsection{Proses Morfologi Bahasa Indonesia \\ Di dalam bahasa Indonesia} pembagian preposisi dibagi atas dua bagian yaitu :

a. Pembagian preposisi menurut asalnya.

1) Preposisi ialah kata depan yang sejak dahulu sampai sekarang berfungsi sebagai kata depan. Bahasa Indonesia mempunyai tiga macam preposisi asli yaitu : di, ke, dari.

2) Preposisi tidak asli ialah kata yang mula-mula berfungsi sebagian kata benda, tetapi kemudian berfungsi 
sebagai kata depan, misalnya : pada, atas, bawah, luar, depan, antara, sampai dengan, tentang, oleh, dan lain-lain (Soekono Wirjosoedarmo, 1984 : 193).

b. Pembagian preposisi menurut susunannya

1) Preposisi tunggal ialah kata depan yang dalam pemakaiannya tidak bergabung dengan kata depan lainnya. Misalnya : di, ke, dari, akan, oleh, tanpa, dengan, untuk, pada.

2) Preposisi majemuk ialah kata depan yang sebenarnya merupakan gabungan dari dua kata depan, misalnya : kepada, di atas, daripada.

c. Pembagian Preposisi menurut Bentuknya

Dintinjau dari segi bentuknya, preposisi dapat dibagi menjadi dua bagian, yaitu : Preposisi Monomorfemis dan Preposisi Polimorfemis. Preposisi monomorfenis adalah preposisi yang terdiri hanya atas satu morfem dan karena itu tidak dapat diperkecil lagi bentuknya. Contoh preposisi ini adalah : di, ke, dari, dengan, buat, untuk, guna, oleh, pada, tentang, karena, dan sebab.

Preposisi polimorfemis terdiri atas dua macam : (1) yang dibentuk dengan memakai afiks, contohnya : selama, bagaikan. (2) yang dibentuk dengan menggambungkan dua kata atau lebih, contohnya : selain dari dan sampai dengan, sampai ke dan lain-lain (Anton M Moeliono, 1993 : 230).

Melihatnya banyak preposisi dalam bahasa Indonesia seperti yang telah diutarakan diatas, peneliti membatasi analisis kontrastifnya pada preposisi monomorfemis saja, yaitu : di, ke, dari, dengan, buat, untuk, guna, oleh, pada, tentang, karena, sebab, bagi dan sejak. Hal ini dimaksudkan supaya tidak terlalu luas dan menyulitkan dalam interpretasi maknanya.
2.2.3. Preposisi Dalam Bahasa Indonesia

Dalam sub-sub ini, peneliti bermaksud menerangkan fungsi preposisi monomorfemis satu-persatu serta pemakaian di dalam kalimat.

1. Preposisi "di"

Preposisi di pada dasarnya berfungsi menyatakan tempat atau menandai hubungan tempat berada.

Contoh :

(1) Dia tinggal di Jakarta.

(2) Di perpustakaan banyak buku.

2. Preposisi "ke"

Preposisi ke pada dasarnya berfungsi menyatakan arah atau tempat yang dituju. Sering dipakai berhubungan dengan kata kerja atau ungkapanungkapan yang beraspek gerak, sedang yang mengikutinya menyatakan tempat. Dengan kata lain fungsi preposisi ke ini adalah menandai hubungan arah menuju suatu tempat. Contoh :

(3) Bulan Maret FIB Undip studi banding ke Leiden University.

3. Preposisi "dari"

Preposisi dari pada dasarnya berfungsi menunjukkan tempat asal atau asal mula suatu proses, unsur, Misalnya :

a. Yang menyatakan tempat asal

(4) Dia datang dari Belanda.

c. Yang menyatakan sebab

(5) Dari itulah kami menolak permohonannya.

d. Yang menyatakan pengertian sejak

(6) Dari pagi rumah itu kosong.

e. Yang menyatakan arti di antara

(7) Seorang dari penjahat itu dieksekusi.

f. Yang menyatakan arti tentang

(8) Dia menulis biografi ayahnya.

g. Yang menyatakan perbandingan

(9) Adiknya lebih cantik dari kakaknya.

h. Yang memakai makna pemisahan 
(10) Dia harus dijauhkan dari lingkungan negatif.

4. Preposisi "dengan"

a. Untuk menyatakan arti bersamasama

(11) Dia pergi ke luar negeri dengan istrinya.

b. Untuk menyatakan arti dengan lawan

(12) Dia berkelahi dengan pencuri.

c. Untuk menyatakan arti sama dengan dan

(13) Ayah dengan ibu tidak pernah bertengkar.

d. Untuk menyatakan kira-kira sama artinya dengan sambil

(14) Dia berpidato dengan santai.

e. Untuk menyatakan alat (mempergunakan alat)

(15) Saya makan dengan sumpit.

5. Preposisi "oleh"

Preposisi oleh pada dasarnya dipakai untuk :

a. Menandai makna pelaku tindakan dalam kalimat pasif.

(16) Bangunan ini diresmikan oleh Presiden.

b. Menandai makna sebab, sejalan dengan pemakaian kata karena

(17) Pipi yang telah kering kembali basah oleh tetesan air mata.

c. Preposisi oleh berfungsi menghubungkan kata kerja dengan objek pelaku secara implisit. Kadang-kadang sifatnya, yakni apabila kata kerja berawalan di langsung diikuti objek pelaku.

(18) Mobil itu dimasukkan oleh Gredy ke dalam garasi.
Dalam beberapa kalimat tertentu kata oleh dipakai tidak boleh dihilangkan yaitu :

a. Apabila kata kerja dan objek pelaku di antarai oleh kata lain.

(19) Barang itu telah dikirimkan dengan pos oleh kakak kemarin.

b. Apabila kata oleh dipakai memulai kalimat.

(20) Oleh ayahnya dibacakannya surat wasiat itu dengan suara yang lirih.

c. Apabila kata oleh menghubungkan kata kerja berawalan ter dengan pelengkap pelaku.

(21) Bukunya terbawa oleh ku.

d. Apabila kata oleh mengikuti kata kerja aus.

(22) Mintalah oleh atasan cuti dalam minggu ini juga.

\section{SIMPULAN}

Dari pemaparan dalam bagian pembahasan di atas, dapat disimpulkan bahwa bahasa Jawa dan bahasa Indonesia dapat diketahui struktur fonologi, morfologi, dan sintaksis. Dari pemaparan itu pula, dapat diketahuai adanya perbedaan yang mencolok dalam struktur fonologi, morfologi, dan sintaksis.

Dalam ranah fonologi terdapat perbedaan tentang keberadaan fonem segmental dan fonem suprasegmental dalam bahasa Jawa, jumlah bunyi vokal bahasa Jawa lebih banyak.

Untuk morfologi terdapat variasi proses morfologi bahasa Indonesia lebih banyak satu proses, yaitu kontraksi. Jumlah proses afiksasi antara bahasa Indonesia lebih banyak dari pada bahasa Jawa. Serta Proses Morfologi bahasa Indonesia lebih kompleks dari pada bahasa Jawa. 
HUMANIKA Vol. 21 No.1 (2015) ISSN 1412-9418

Analisis Kontrastis Bahasa Jawa Dengan Bahasa Indonesia

Riris Tiani

\section{DAFTAR PUSTAKA}

Keraf, Gorys. 1980. Tata Bahasa Indonesia. Ende Flores: Nusa Indah

Mulyana, Anton, et al. 2010. Tata Bahasa Baku Bahasa Indonesia. Jakarta: Balai Pustaka
Parera, JD. 1983. Pengantar Linguistik Umum. Ende Flores : Nusa Indah.

Ramlan. 1982. Kata Depan atau Preposisi dalam Bahasa Indonesia. Yogyakarta : CV Karyono.

Samsuri. 1975. Morfosintaksis. IKIP Malang 